\title{
Frequency of leucism in a colony of Anoura geoffroyi (Chiroptera: Phyllostomidae) roosting in a ferruginous cave in Brazil
}

\author{
Aline da Silva Reis ${ }^{1 *}$, Robson de Almeida Zampaulo² \& Sônia Aparecida Talamoni ${ }^{I}$ \\ ${ }^{1}$ Pontificia Universidade Católica de Minas Gerais, Belo Horizonte, MG, Brasil \\ ${ }^{2}$ Vale S.A., Licenciamento e Espeleologia da Diretoria de Planejamento de Ferrosos, Rio de Janeiro, RJ, Brasil \\ *Corresponding author: Aline da Silva Reis,e-mail: alineambiental@yahoo.com.br
}

REIS A.S., ZAMPAULO R.A., TALAMONI S.A. Frequency of leucism in a colony of Anoura geoffroyi (Chiroptera: Phyllostomidae) roosting in a ferruginous cave in Brazil. Biota Neotropica. 19(3): e20180676. http://dx.doi.org/10.1590/1676-0611-BN-2018-0676

\begin{abstract}
We provide the first report of the frequency of leucism for a species of Neotropical bat. Leucism is an anomaly of the skin pigmentation of an animal that manifests itself as the total or partial loss of the natural color of the species, and can affect part of or the entire body. During a study involving capture and marking individuals of a population of $A$. geoffroyi residing in a cave in the Brazilian state of Minas Gerais, seven individuals with some degree of depigmentation were recorded out of 616 individuals marked, for a frequency of $1.1 \%$. Since leucism is due to recessive gene expression, these findings may indicate that the population is isolated and possesses a high level of endogamy. Factors that may be responsible for this condition in the studied population remain unknown. Keywords: Glossophaginae, hypopigmentation, bats, Iron Quadrangle.

\section{Frequência de leucismo em uma colônia de Anoura geoffroyi (Chiroptera: Phyllostomidae) abrigada em uma caverna ferruginosa no Brasil}

Resumo: Relatamos aqui o primeiro registro de frequência de leucismo em uma espécie de morcego Neotropical. Leucismo é uma anomalia na pigmentação da pele dos animais que consiste na perda total ou parcial da cor natural da espécie, podendo acometer partes ou todo o corpo do animal. Em um estudo de captura e marcação de indivíduos de uma população de $A$. geoffroyi abrigada em uma caverna localizada no estado de Minas Gerais, foram registrados sete indivíduos com algum grau de despigmentação dentre 616 indivíduos marcados, representando $1.1 \%$ da população. Leucismo é um tipo de anomalia de coloração de expressão gênica recessiva, portanto, esse resultado pode indicar isolamento da população e nível elevado de endogamia. Fatores que podem levar à esta condição nessa população são desconhecidos.
\end{abstract}

Palavras-chave: Glossophaginae, hipopigmentação, morcegos, Quadrilátero Ferrífero.

\section{Introduction}

Leucism is an anomaly of the pigmentation of the skin of animals and manifests itself as the total or partial loss of the natural color of the species, and can affect parts of or the entire body of an individual (Miller 2005; Acevedo \& Aguayo 2008). Differing from albinism, in which individuals have red eyes due to the total lack of pigmentation, leucistic individuals retain their normal eye color but exhibit hypopigmentation in the pelage, which can be partial or total (Fertl \& Rosel 2002; Marín-Vasquez et al. 2010; Abreu et al. 2013).

The occurrence of pigmentation anomalies in wild populations is apparently rare (Walter 1914; Sánchez-Hernández et al. 2010; Talamoni et al. 2017). The low frequency of these phenotypes is attributed to the higher susceptibility of these animals to predation (Sazima \& Di-Bernardo 1991; Parsons \& Bonderup-Nielsen 1995). According to Walter (1938), only one in every 20,000 individuals has some form of albinism. Pigmentation abnormalities have been recorded in fish, reptiles, birds and mammals (Uieda 2000, Abreu et al. 2013); such abnormalities occur more frequently in small and isolated populations due to inbreeding, which increases the likelihood that recessive alleles are expressed (Bensch et al. 2000).

There have been several recent reports of leucism for phyllostomid bats (Boada \& Tirira 2010; Marín-Vasquez et al. 2010; Medina \& López 2010; Sánchez-Hernández et al. 2010; García-Morales et al. 2012; López-Wilchis \& Galván 2012; Rocha et al. 2013; Treitler et al. 2013; Brito \& Leon 2014; Trujillo \& Barahona 2014; Biassi et al. 2017), molossid bats (Caire \& Thies 1988; Barquez et al. 2003; Geiger $\&$ Pacheco 2006), and vespertilionid bats (Barquez et al. 2003; Idoeta et al. 2011). Nonetheless, even though microchiropterans represent a group with the second greatest number of reported cases of leucism among Neotropical mammals (Abreu et al. 2013), there remains a lack of studies addressing the factors related to its occurrence in bats. 
Complete depigmentation of the skin, or albinism, in Anoura geoffroyi (Gray, 1838) has been reported in Trinidad and Tobago in the southern Caribbean, where a young individual was observed inside a cave (Hargreaves 2013). Although, in this case, the author does not present population data or number of individuals collected. Herein, we provide the first report of the frequency of partial hypopigmentation for a bat colony, using a small cave in an iron formation in the Quadrilátero Ferrífero (Iron Quadrangle) in Southeast Brazil as a diurnal roost, which was be monitored with the mark-recapture method.

\section{Material and Methods}

The studied colony utilizes the cave MJ-05 (WGS $84-20^{\circ} 5$ '40.27'S and $44^{\circ} 4^{\prime} 36.07^{\prime \prime} \mathrm{W}-1.072 \mathrm{~m}$ a.s.1), located in the municipality of Brumadinho, in the metropolitan area of Belo Horizonte, state of Minas Gerais, Brazil (Figure 1). The municipality of Brumadinho is located in the Quadrilátero Ferrífero (Iron Quadrangle), which is considered one of the most important mineral provinces in the country mainly due to its gold and iron deposits (Dorr 1969). The climate of the region is of the Cwb type, and classified as subtropical at altitude, with dry winters and rainy summers (Ribas 2010). The municipality is located in a region dominated by semideciduous seasonal forests, high-montane fields and campos rupestres (rupestrian grasslands) (Markus 2003).
Captures were performed only in the cave MJ-05 between March 2017 and February 2018, during monthly daytime visits to the roost that lasted 8 hours each for a total of 12 field days and 96 hours of captures. Bats were captured using a 2-m long retractable rod. The captured bats were marked with an aluminum band coupled to a necklace. The bands were sequentially numbered with the number preceded by AR to facilitate the identification of individuals in the case of recapture. The captured individuals were weighed, measured, marked and released.

All of the procedures performed during the work were authorized by Instituto Chico Mendes de Conservação da Biodiversidade (ICMBio) issued by SISBio (\#55700/2). The handling of the animals was also licensed by the Comissão de Ética no Uso de Animais (\#019/2016). Voucher material was deposited in the reference collection of the mastozoology laboratory of Pontifícia Universidade Católica de Minas Gerais.

\section{Results and Discussion}

A total of 616 individuals of Anoura geoffroyi were captured, of which seven individuals exhibited patches of hypopigmentation characteristic of leucism, representing $1.1 \%$ of the population. The leucistic individuals were captured in April, June, July, September,
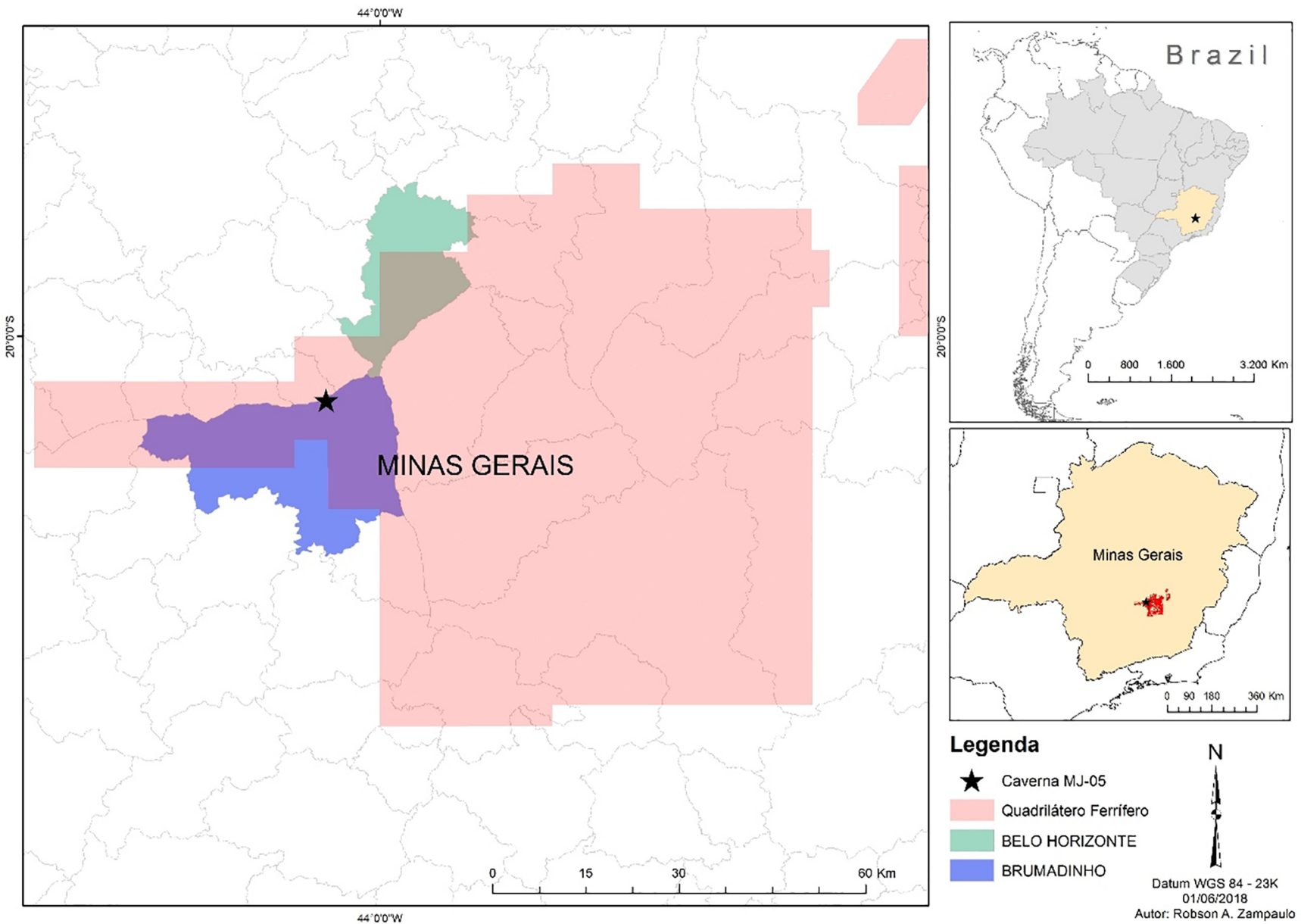

Figure 1. Location of cave MJ-05 in the municipality of Brumadinho, state of Minas Gerais, Brazil. The Quadrilátero Ferrifero (Iron Quadrangle) is shown in pink. 
October and November and comprised four males and three females (Table 1). These bats were examined, marked and had their patches photographed, and then were released in the cave, with the exception of the individual that was sacrificed and kept as a voucher specimen (MZ694).

The leucistic individual AR076 had depigmentation on the patagium between metacarpals III and V (Figure 2A); the individual AR121 had greater depigmentation at the base of the right ear, tragus and rostrum (Figure 2B). The voucher specimen had more evident depigmentation, encompassing both ears, a region on both forearms and in the plagiopatagium near the body (Figure 2C and D). The individuals AR205, AR300, AR323 (Figure 2E) and AR361 exhibited depigmentation of parts of the patagium and the extremity of the wing. Among these individuals, AR300 possessed many spots of depigmentation, with several small white spots on both wings (Figure 2F).

This is the first case of leucism formally reported for this species in Brazil. Reports of hypopigmentation in bats are usually sporadic, and are usually obtained by chance during chiropteran surveys (Geiser \& Pacheco 2006; Rocha et al. 2013; Biassi et al. 2017).

Under normal conditions, albino mammals are negatively selected because they are more visible to predators (Parsons \& Bondrup-Nielsen 1995). The greater vulnerability of albino animals to predation (Parsons \& Bondrup-Nielsen 1995; Uieda 2000) can be extrapolated, to some degree, to other types of hypopigmentation, since such individuals possess, to a lesser or greater extent, physical characteristics that make them more visible.

The nocturnal behavior of bats may make them relatively less vulnerable to predation than most diurnal animals, although individuals affected by the mutation are more visible in their diurnal roosts than other bats (Rocha et al. 2013). Individuals affected by melanic mutations seek shelter in caves, mines, galleries and buildings in order to reduce predation pressure (Uieda 2000). Cave-dwelling behavior, as observed in the present study, may be essential for the survival of bats with depigmentation, since these environments provide protection against sunlight, water loss and visually oriented predators (Uieda 2000; Buys, Hejligers \& Dorenbosch 2002).

Studies carried out with birds found that individuals with leucism and albinism have relatively shorter life spans in nature compared to normal individuals, since they are more frequently found by predators due to their attractive and distinct color (Santos 1981; Collins 2003).
Corroborating these studies, Sazima \& Di-Bernardo (1991) observed that cases of hypopigmentation are recorded more frequently in nocturnal species, cryptic species or species that are somehow protected from diurnal and visually oriented predators, which may explain the relatively high incidence of anomalous color patches in bats, as previously reported (Abreu et al. 2013).

Depigmentation in mammals represents a disadvantage in various ecological and biological contexts (Caro 2005). In addition to making mutated animals more susceptible to predation, depigmentation also hinders intraspecific communication and recognition and, in some cases, causes these individuals to be removed from social groups (Caro 2005). In the present study, we did not observe behaviors of exclusion of the leucistic individuals, and they were always captured amongst other bats that did not possess any such anomaly.

We observed that $1.1 \%$ of the population had some degree of depigmentation, which greatly exceeds the degree of rarity reported by Walter (1938) for albinism. According to this author, only one in 20,000 individuals may possess some form of albinism. Thus, we can assume that our results indicate a relatively high degree of anomalous coloration in the studied population, although no genetic study could be found that could give some kind of foundation. Considering that leucism is due to recessive gene expression (Møller \& Moussaeu 2001), our results suggest that the studied population is isolated and that endogamy is occurring, as previously observed for birds by Bensch et al. (2000).

It is necessary to know the reasons that cause the appearance of these genetic anomalies of pelage coloration and their consequences for the affected individuals (Chacón et al. 2015). The need for genetic studies aimed to better understand these anomalies is in contrast to the low number of reports in Neotropical mammals in general (Abreu et al. 2013). Therefore, it is important that researchers report the occurrence of coloration anomalies in order to have a true dimension of the number of animals affected and thus facilitate the search for the causes and consequences of this phenomenon in bats and mammals in general (García-Morales et al. 2010).

Finally, it should be noted that the studied colony is located in an area of influence of mining activity. These areas suffer from severe impacts such as habitat suppression that may increase the isolation levels of bat populations occurring at these sites. In addition, these populations may be subject to more drastic impacts, such as the recent dam rupture at the Córrego do Feijão mine in the municipality of Brumadinho, located approximately 5 kilometers from the MJ-05 cave. Fortunately

Table 1. Date of collection, identification, forearm size (mm), body mass (g), sex and age of leucistic bats captured in a cave of the Quadrilátero Ferrífero (Iron Quadrangle), state of Minas Gerais, Brazil.

\begin{tabular}{|c|c|c|c|c|c|}
\hline Capture date & Identification & Forearm length & Body mass & Sex & Age \\
\hline Apr 28, 2017 & AR076 & 41.2 & 13.4 & Male & Subadult \\
\hline Jun 27, 2017 & AR121 & 42.4 & 16.5 & Male & Adult \\
\hline Sep 25, 2017 & AR205 & 42.7 & 13.0 & Female & Adult \\
\hline Oct 31,2017 & AR323 & 41.7 & 12.0 & Female & Adult \\
\hline \multicolumn{2}{|c|}{ Mean } & 41.7 & 13.8 & & \\
\hline \multicolumn{2}{|c|}{ Standard deviation } & 0.9 & 1.7 & & \\
\hline
\end{tabular}



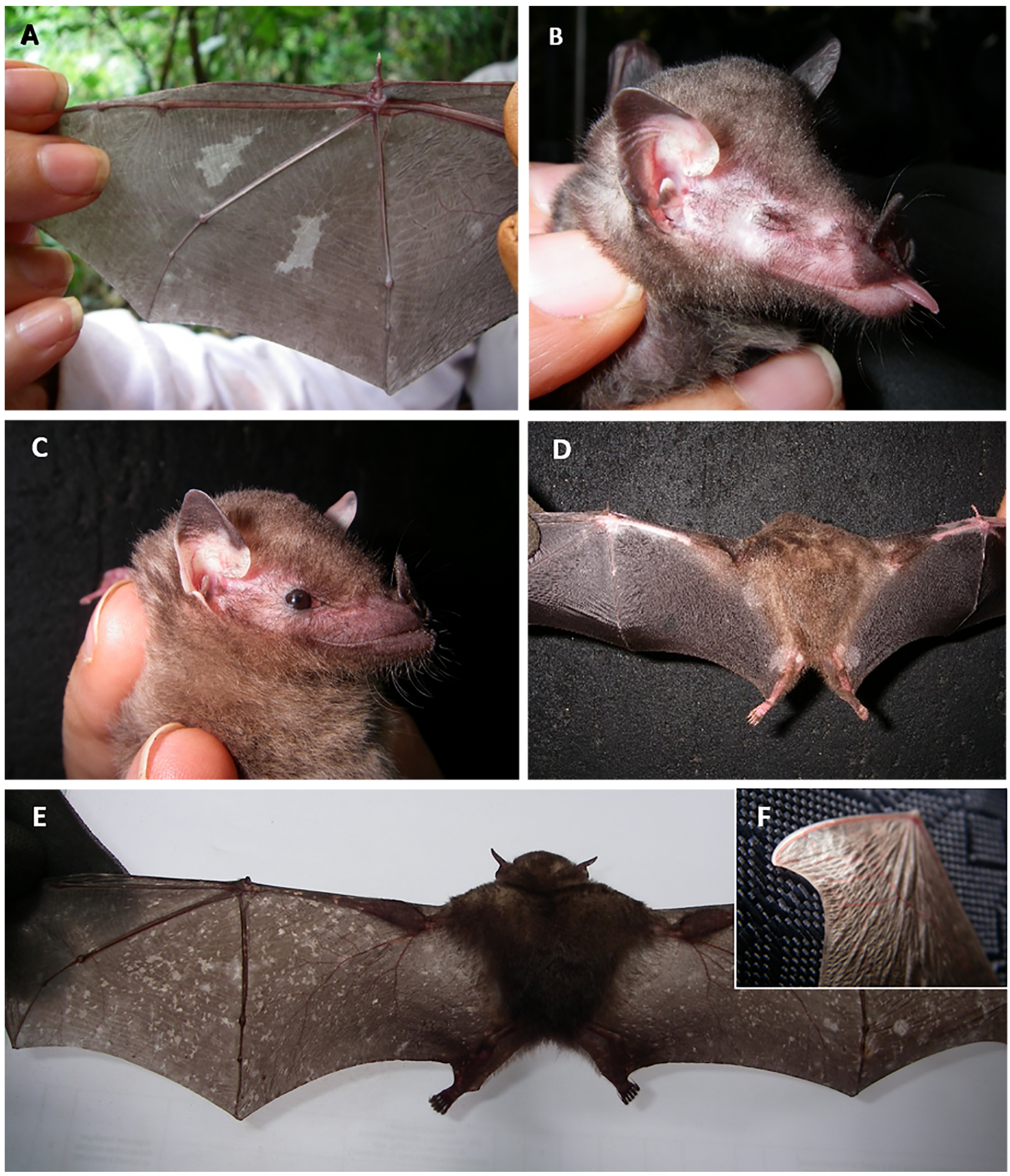

Figure 2. Specimens of Anoura geoffroyi with leucism captured in cave MJ-05 located in the municipality of Brumadinho, Minas Gerais, Brazil. A. Individual AR076 with detail of depigmentation of the wing between metacarpals III and V. B. Individual AR121 with depigmentation at the base of the ear, tragus and part of the rostrum. C and D. Specimen (voucher specimen MZ694) of Anoura geoffroyi with leucismo - Detail of depigmentation of the ears and plagiopatagium near the body. E. Individual AR300 with detail of depigmentation at several points on the wings. F. Individual AR323 with depigmentation at the extremity of the wing. 
this rupture did not affect the shelter of the studied colony. However, for this population, the effects of the environmental destruction caused in the region can only be evaluated in future studies.

\section{Acknowledgments}

We are grateful to Vale S.A., represented by the Gerência de Espeleologia (DIFP), for allowing access to the area where the cave is located and for providing logistical support to carry out the study. We thank William Demétrio, in particular, for his dedication during fieldwork. We thank CEUA and Instituto Chico Mendes de Conservação da Biodiversidade ICMBio for granting licenses, Pontifícia Universidade Católica de Minas Gerais (PUC Minas) for the scholarship awarded and FIP-PUC Minas for financial support of the project.

\section{Author Contributions}

Aline da Silva Reis: Substantial contribution in the concept and design of the study; Contribution to data collection; Contribution to data analysis and interpretation; Contribution to manuscript preparation.

Robson de Almeida Zampaulo: Substantial contribution in the concept and design of the study; Contribution to data collection; Contribution to data analysis and interpretation; Contribution to manuscript preparation.

Sônia Aparecida Talamoni: Contribution to data analysis and interpretation; Contribution to manuscript preparation; Contribution to critical revision, adding intelectual content.

\section{Conflicts of interest}

The authors declare that they have no conflict of interest related to the publication of this manuscript.

\section{References}

ABREU, M.S.L., MACHADO, R., BARBIERI, F., FREITAS, N.S. \& OLIVEIRA, L.R. 2013. Anomalous colour in Neotropical mammals: a review with new records for Didelphis sp. (Didelphidae, Didelphimorphia) and Arctocephalus australis (Otariidae, Carnivora). Braz. J. Biol. 73(1):185-194

ACEVEDO, J. \& AGUAYO, M. 2008. Leucistic South American sea lion in Chile, with a review of anomalously color in ottarids. Rev. Biol. Mar. Oceanogr. 43(2):413-417.

BARQUEZ, R.M., CARRIZO L.V., FERRO, L.I., FLORES, D.A., MOLlERACH, M.A., SÁNCHEZ, M.S. \& GARCÍA, A.P. 2003. Primer caso de albinismo total para Sturnira erythromos (Tschudi, 1844) (Chiroptera: Phyllostomidae). Chiroptera Neotropical 9:166-169.

BENSCH, S.B., HANSSON, D., HASSELQUIST, B. \& NIELSEN. 2000. Partial albinism in a semi-isolated population of Great Reed Warblers. Hereditas 133:167-170.

BIASSI, D.L., NERES, A.P. \& D’AGOSTINI, F.M. 2017. Registro de leucismo em Sturnira lilium (E. geoffroyi, 1810) (Chiroptera: Mammalia) no sul do Brasil. Rev. Bras. Biosc. 15 (2):96-98.

BOADA, C. \& TIRIRA, D.G. 2010. First record of partial albinism (leucism) in Carollia perspicillata (Phyllostomidae) in Ecuador. Chiroptera Neotropical 16:755-757.

BRITO, J. \& LEÓN, C. 2014. Primer caso de albinismo en Vampyrum spectrum (Chiroptera: Phyllostomidae) para Ecuador. Mammalogy Notes 1:14-15.
BUYS, J., HELJIGERS, H. \& DORENBOSCH, M. 2002. First record of an albino long-ears bat Plecotus auritus in the Netherlands. Lutra 45(1):49-52.

CARO, T. 2005. The adaptive significance of coloration in mammals. BioScience 55(2):125-137.

CAIRE, W. \& THIES, M. 1988. Notes on the occurrence of morphological and color aberrations in bats from Oklahoma, Missouri, and Mexico. Proc Okla Acad Sci. 68:75-75.

CHACÓN, P.J.J., GONZÁLEZ CHARRASQUIEL, C.M. \& BALLESTEROS CORRREA, J. 2015. Records of leucism in Artibeus planirostris (Chiroptera: Phyllostomidae) in Colombia. Acta Zool. Mex. 31(1):125-128.

COLLINS, C.T. 2003. A leucistic Willet in California. Western Birds 34:118-119.

DORR, J.V.N. 1969. Physiographic, stratigraphic and structural development of the Quadrilátero Ferrífero, Minas Gerais, Brazil. Paper USGS/Geological Survey Professional, 611:1-117.

FERTL, D. \& ROSEL, P. 2002. Albinism. In Encyclopaedia of Marine Mammals (W.F. PERRIN, B. WÜRSIG \& J.G.M. THEWISSEN, eds). Academic Press, San Diego, p.16-18.

GARCÍA-MORALES, R., GORDILLO-CHÁVEZ, E.J. \& BELLOGUTIÉRREZ, J. 2010. Primer registro de albinismo en Glossophaga soricina (Phyllostomidae) en México. Chiroptera Neotropical 16(2):743-747.

GARCÍA-MORAlES, R., TEJADA, D., ÁVILA, E., MORENO, C. \& AKMENTINS, M. 2012. Registro de leucismo en Sturnira ludovici y Artibeus jamaicensis (Phyllostomidae) en México. Chiroptera Neotropical 18:1101-1105.

GEISER, D \& PACHECO, S. M. 2006. Registro de Albinismo parcial em Nyctinomops laticaudatus (E. Geoffroy, 1805) (Chiroptera: Molossidae) no sul do Brasil. Chiroptera Neotropical 12 (1):250-254.

HARGREAVES, D. Trinibats: Trinidad and Tobago, West Indies. Disponível em: http://www. trinibats.com/uploads/1/0/6/2/10624406/trinibats report march_2013.pdf. Acesso: 14 mar. 2018.

IDOETA, F.M., SANTIS, L.J.M. \& BÁRQUEZ, R.M. 2011. Leucismo en Eptesicus furinalis (d'Orbigny y Gervais, 1847) (Chiroptera: Vespertilionidae) en la provincia de Corrientes, Argentina. Chiroptera Neotropical 17:985-988.

LÓPEZ-WILCHIS, R. \& GALVÁN, M.A.L. 2012. A noteworthy case of leucism in Artibeus lituratus (Chiroptera: Phyllostomidae) from Oaxaca, Mexico. Chiroptera Neotropical 18(1):1111-1114.

MARÍN-VÁSQUEZ, A., ORTEGA-RINCÓN, M. \& RAMIREZ-CHAVES, H.E. 2010. Records of leucism in three species of Colombian bats: Carollia brevicauda, Artibeus jamaicensis and Lophostoma silvicolum (Phyllostomidae). Chiroptera Neotropical 16:706-709.

MARKUS, M. 2003. Avaliação das áreas de preservação permanente na microbacia do Ribeirão da Casa Branca - Brumadinho. MG. (Monografia de Especialização). Universidade Federal de Minas Gerais, Instituto de Geo Ciências, Especialização em Geoprocessamento, Belo Horizonte.

MEDINA, C. \& LÓPEZ, E. 2010. Primer registro de leucísmo en Sturnira lilium (Phyllostomidae) en el Sureste del Perú. Chiroptera Neotropical 16:755-757.

MØLLER, A.P. \& MOUSSAEU, T.A. 2001.Albinism and phenotype of barn swallows (Hirundo rustica) from Chernobyl. Evolution 55:2097-2104.

MILLER, J.D. 2005. All about albinism. Missouri Conservationist 66:5-7.

PARSONS, G.J. \& BONDERUP-NIELSEN, S. 1995. Partial albinism in an island population of Meadow Voles, Microtus pennsylvanicus, from Nova Scotia. Can. Field-Nat. 109:263-264.

RIBAS, P.R. 2010. Mapeamento de córregos de cabeceira sob dosséis florestais utilizando dados lidar. Universidade Federal de Minas Gerais (UFMG) Revista Brasileira de Cartografia. 63:1-7.

ROCHA, P.A., FEIJÓ, J.A., DONATO, C.R. \& FERRARI, S.F. 2013. Leucism in Seba's short-tailed bat, Carollia perspicilata (Linnaeus, 1758), from a rock shelter in northeastern Brazil. Chiroptera Neotropical 19(1):1151-1153.

SANTOS, T. 1981. Variantes de plumaje y malformaciones en Turdus spp. Ardeola 28:133-138. 
Reis, A.S. et al.

SÁNCHEZ-HERNÁNDEZ, C., ROMERO-ALMARAZ, M.L., TABOADASALGADO, A., ALMAZÁN-CATALÁN, J.A., SCHNELL, G.D. \& SÁNCHEZ-VÁZQUEZ, L. 2010. Five albino bats from Guerrero and Colima, Mexico. Chiroptera Neotropical 16:541-545.

SAZIMA, I. \& DI-BERNARDO, M. 1991. Albinismo em serpentes neotropicais. Mem. Inst. Butantan 53(2):167-173.

TALAMONI, S., VIANA, P.I.M., COSTA, C.G., PALÚ, L., OLIVEIRA, R.B., PESSÔA, L.M. Occurrence of leucism in Eira barbara (Carnivora, Mustelidae) in Brazil. Biota Neotropica. 17(3): e20170328. http://dx.doi. org/10.1590/1676-0611-BN-2017-0328 (last access on 09/10/2018)
TREITLER, J.T., BAUCELLS, A.L., FARIAS, S.G., TENAÇOL JÚNIOR, J.F. \& ROCHA, R. 2013. First record of a leucistic piebald Phyllostomus discolor (Chiroptera: Phyllostomidae). Chiroptera Neotropical 19:1179-1181.

TRUJILLO, L.A. \& BARAHONA, R. 2014. First record of leucism in Artibeus phaeotis (Miller, 1902) (Chiroptera: Phyllostomidae) from Guatemala. Chiroptera Neotropical 20:1252-1254.

UIEDA, W. 2000. A review of complete albinism in bats with five new cases from Brazil. Acta Chiropterol. 2:97-105.

WALTER, H.E. 1914. Genetics: An Introduction of Study of Heredity. New York: Mac-Millan.

Received: $12 / 10 / 2018$

Revised: 27/02/2019

Accepted: 26/03/2019

Published online: 18/04/2019 